\title{
A Goldsmith of the American Revolution
}

\author{
THE WORKING LIFE OF PAUL REVERE
}

\section{Bernard Caccia}

One adventurous incident in the life of Paul Revere has established his fame for evermore as a hero of the American Revolution. His midnight ride in 1775 from Charlestown to Lexington to arouse the colonists and warn them of the approach of the British troops was not the only occasion when he acted as mounted messenger for the "rebels", while on that famous night there were other riders engaged on the same mission, but thanks to Longfellow the name of Paul Revere is uniquely honoured.

But for the greater part of his long life Revere was occupied in the less exciting role of a working goldsmith. His father, descended from a Huguenot family forced to leave their native France in 1685, was christened Apollos De Rivoire. As a boy of 13 he left Guernsey in 1715 for America to learn the craft of the goldsmith and settled in Boston. There, for the benefit of his new English-speaking acquaintances, he anglicised his name to Paul Revere, and after an apprenticeship lasting ten years he set up for himself.

$\mathrm{He}$ prospered sufficiently to marry in 1729 , and the younger Paul, one of seven children, was born on January 1st, 1735. The son's schooldays were spent at the North Grammar School in Boston, but in his home background he was undoubtedly immersed in the goldsmith's art being practised around him, and on leaving school he at once joined his father in the workshop. Here he showed an aptitude not only for the manual work involved but also for design.

Many years later, in a letter to his cousin Mathias Rivoire, he wrote:

\begin{abstract}
"My father was a goldsmith, he died in 1754, he left no estate, but he left a good name and seven children. I was the eldest son. I learned the trade of him and have carried on the business ever since; until the year 1775 when the American Revolution began; from that time till May 1780, I have been in the government service as Lieut. Col. of an Artillery regiment-the time for which that was raised then expired and I thought it best to go to my business again, which I now carry on."
\end{abstract}

There were at this period a surprising number of goldsmiths, silversmiths and jewellers operating in the colonies of Virginia, New York and New England.

Probably one of the last pieces made by Paul Revere in his long career as a goldsmith was this gold urn to hold a lock of George Washington's hair. It was commissioned by the Grand Lodge of Massachusetts, of which Revere was a Past Grand Master, and is still preserved in their care.
All of them offered "the highest price" for old gold and silver, and often specified that sales were "for ready money only". There was of course no primary source of gold available, and no gold refinery existed until well after the revolution, when a decree of the Government of the United States authorised the establishment of the Philadelphia Mint in 1792. Goldsmiths had therefore to rely for their starting materials entirely upon customers bringing in old pieces for melting down or on coins from a number of countries such as France, Spain, Portugal, Mexico and Peru-the romantically named pieces of eight, doubloons, pistoles, crusadoes, and so on. Any refining of gold needed was carried out by the individual goldsmith, whose apprenticeship training included instruction in nitric acid parting.

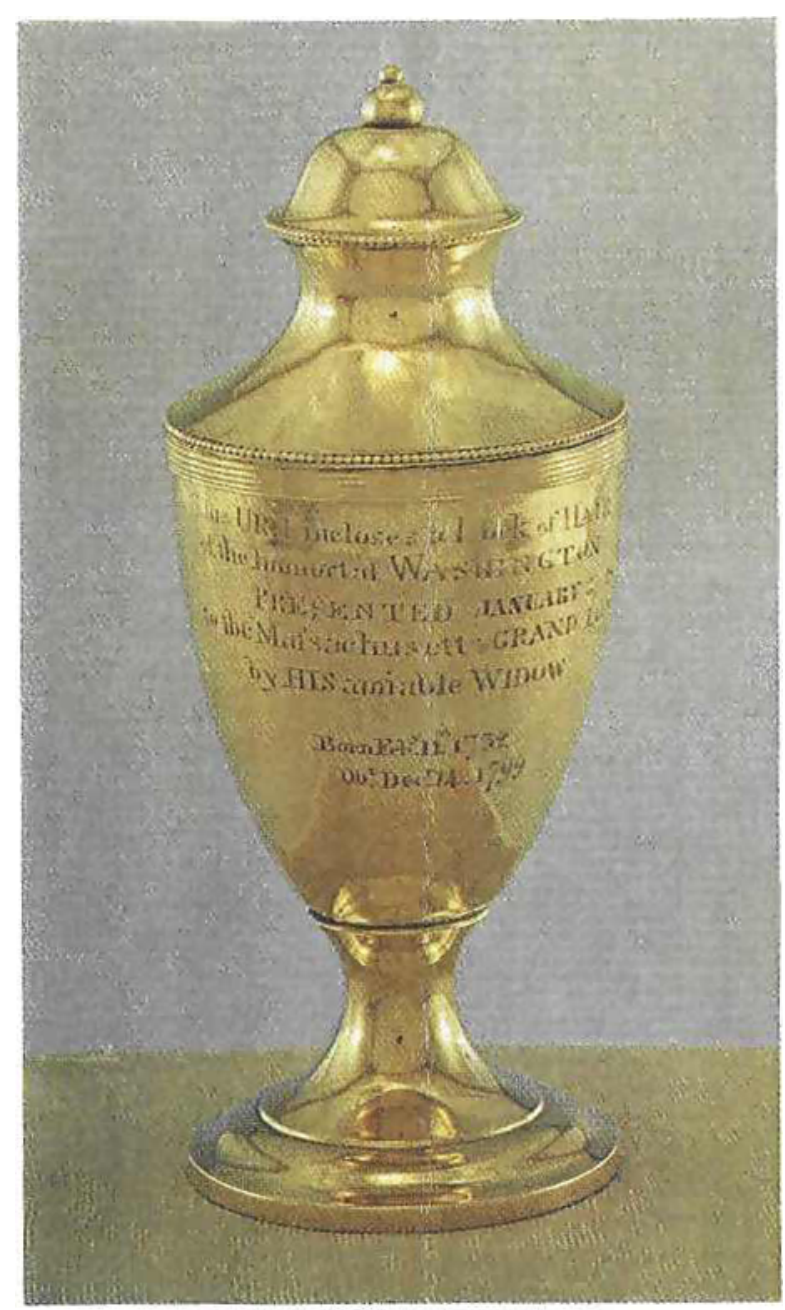


Paul Revere at the age of 66 . This portrait is a erayon drawing made in 1801 by C. B. J. F. de St Memin and is now in the Museum of Fine Arts in Boston. Revere lived another seventeen years, dying at the age of 83 in 1818 . For more than half a century he was a practising goldsmith.

Courtesy of the Museum of Fine Arts, Boston

Revere's ledgers have survived for the period 1761 to 1797-with of course the gap of five years when he was not following his trade-and are preserved in the Museum of Fine Arts in Boston. They disclose a flourishing and extensive business in all types of gold and silver ware, including a considerable number of medals and jewels for Masonic Lodges. He was an early and active member of St. Andrew's Lodge in Boston, and it was through his Masonic associations that probably his most famous creation in gold came to be produced in his later years.

On the death of George Washington in December 1799, the Grand Lodge of Massachusetts decided to have a golden urn prepared as a depository for a lock

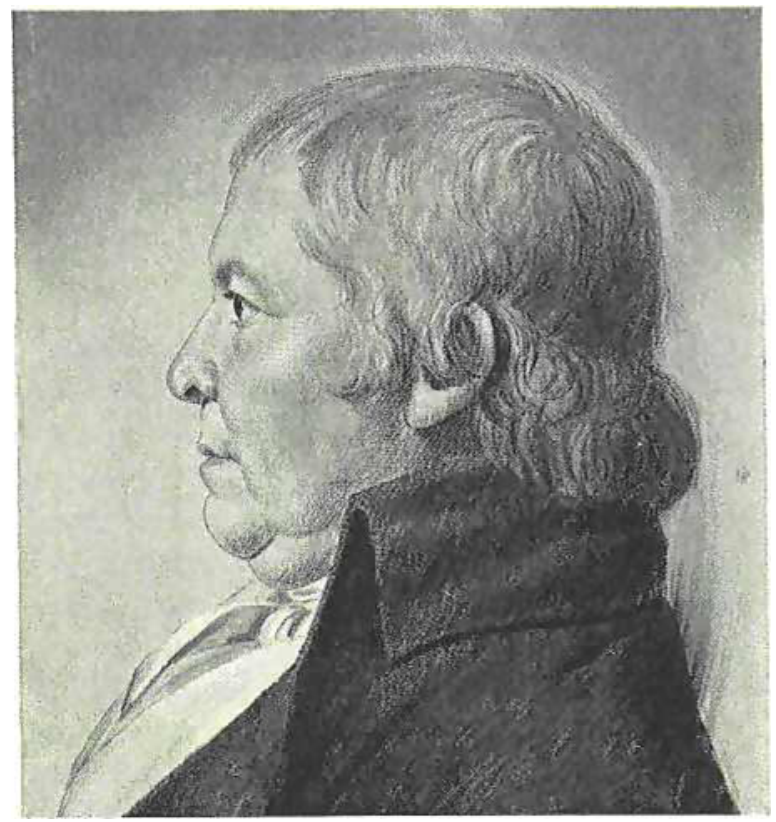

of his hair. The urn was duly made by Paul Reverehimself a Past Grand Master-and is still in the safe keeping of the Grand Lodge in Boston.

\section{A goodlye waye to make Golde in pouder, a thinge easye to be done, and there wyll come of it an excellent coloure. $\tau$ this is a verye rare secrete, which bath not bene used nor known untyll this present}

Take leaves of golde a crowne weighte, or as much as you will, and set it to the fyre in some little cleane pan or pipkin, and in another vessell you shall put foure times as muche in weighte of quicke silver, a good waye from the fyre, so that it may but only warme a little, for otherwise it mighte vanishe awaye. Let not the leaves of golde take so much heate that they melt, but let them warme almost redde. This doen, take them from the fyre, and the quicke silver lykewise, whiche you shall poure hot upon the leaves of golde, and mingle them well together with a little stick, the space of a Paternoster, and poure it afterwarde into a dyshe full of cleare water. You must strain it through a lynnen cloth, tyne and thicke, to the intent that a parte of the quicke sylver maye go throrough or elles straine it thorough a wylde goates skynne, or a lambes skinne, whiche is farre better, and presse it harde, to the intente there may come out as much quicke sylver as possible. Then take that remayneth in the cloth or skynne, and put it to halfe as much fayre quick Brymstone citrine and mingle it with the saied paste: and beynge so myngled, sette it on the fyre in a dysshe or iron ladle, leaving it so untyll all the Brymstone be burned, and all the rest yellowe. Then let it coole, and put it in a dish washynge it so often with cleare water, tyll you have a fayre colour of Golde.

From the translation by

Wyllyam Warde,

The Secretes of the Reverende Master

Alexis of Piemont

London, 1558
ALLESSIO PIEMONTESE

De Secreti

Venice, 1555 